DOI: https://doi.org/10.32689/2523-4536/63-17

УДК 658.152

Жила I. B.

кандидат економічних наук, доцент, доцент кафедри обліку та оподаткування,

Навчально-науковий інститут управління, економіки та бізнесу, ВН3 «Міжрегіональна Академія управління персоналом», м. Київ

Zhila Iryna

Candidate of Economic Sciences, Associate Professor,

Associate Professor of the Department of Accounting and Taxation, Educational and Scientific Institute of Management, Economics and Business, University «Interregional Academy of Personnel Management», Kyiv

\title{
ВИКОРИСТАННЯ АНАЛІТИЧНИХ ДАНИХ ДЛЯ ОБГРУНТУВАННЯ ВИБОРУ ПАКЕТІВ ЦІННИХ ПАПЕРІВ
}

\author{
USE OF ANALYTICAL DATA TO JUSTIFY THE CHOICE \\ OF SECURITIES PACKAGES
}

\begin{abstract}
У статті розглянуто практичні аспекти використання аналітичних даних для розрахунків з обтрунтування вибору пакетів цінних паперів як складників інвестиційного портфеля. Визначено особливості формування інвестиційного портфеля. Складність, багатоаспектність і недостатня розробленість низки питань, пов'язаних з інвестуванням у иінні папери, формуванням інвестиційного портфеля, їх фінансовим аналізом, зумовили актуальність потреби наукового осмислення й аналізу питань аналітичного забезпечення специфічних інформаційних потреб зацікавлених користувачів - професійних учасників фондового ринку. Разом із тим залишається поза увагою низка питань щодо раціонального використання аналітичних даних під час розрахунків, пов 'язаних із формуванням інвестиційного портфеля.

Ключові слова: інвестиційний портфель, інвестиційна діяльність, фактична дохідність, коваріація, коефіцієнт кореляції.

The article examined the practical aspects of analytical data for calculations to substantiate choice of packages of securities as part of the investment portfolio. Features of the investment portfolio were specify. The complexity, multifaceted nature and lack of development of a number of issues related to investing in securities, investment portfolio formation, their financial analysis, led to the need for scientific understanding and analysis of analytical support of specific information needs of interested users - professional stock market participants. However, they do not pay attention to a number of issues regarding the rational use of analytical data in the calculations associated with the formation of the investment portfolio. An investment portfolio is a collection of assets and may include investments such as stocks, bonds, mutual funds and exchange traded funds. An investment portfolio is more of a concept than a physical space, especially in the digital age, but it can be helpful to think of all your assets under one metaphorical roof.As the digital generation ages, the demand for digital supply from traditional financial service providers is growing. Perhaps more importantly, digital investment solutions reduce the cost of providing financial services through automation, artificial intelligence, and machine learning technologies, replacing human decision-making with algorithmic decision-making. After all, work does not require a desk, lunch breaks or pension contributions. To stay relevant and competitive, traditional financial institutions must accept this before they start losing customers because of competitors they already have.Portfolio investment is a passive investment of securities in a portfolio, made for profit. The profit is directly proportional to the risk. The composition of portfolio investments may depend on a number of factors, such as the investment horizon, the risk tolerance of investors and the amount invested. A young investor with limited funds may choose mutual funds or exchangetraded funds, as they may be appropriate portfolio investments. For a wealthy person, this includes goods, real estate and wood. In line with the concept of data dissemination and ever-increasing technological advances, practitioners say that in the future, most data will be created and transmitted through machines, as machines communicate with each other through data networks.
\end{abstract}

Keywords: investment portfolio, investment, real returns, covariance, correlation coefficient.

Постановка проблеми. Сутність портфельного інвестування полягає у розподілі наявних інвестиційних ресурсів між різними видами активів залежно від того, які цілі переслідуються під час формування конкретного портфеля. Різноманіття інвестиційних портфелів класифікується за двома основними ознаками: джерелом доходу від цінних паперів, що формують портфель, та ступенем ризику.

Практично цінні папери забезпечують одержання доходу одним із двох шляхів: за рахунок зростання їхньої курсової вартості або за рахунок отримання додаткових доходів у вигляді дивідендів на акції та у вигляді купонного доходу по облігаціях.

Аналіз останніх досліджень і публікацій. Питання щодо формування інвестиційного портфеля знайшли своє відображення у працях зарубіжних авторів, таких як В. Беренс, Е. Грант, Д. Дін, Г. Марковіц, Р. Пайк. У. Шарп, та у вітчизняних: Е.Ю. Антипенка, Л.О. Бакаєва, І.О. Бланка, А.А. Пересади, В.П. Савчука, М.А. Колісника тощо. 
Мета статті полягає в обгрунтуванні вибору пакетів цінних паперів за рахунок використання аналітичних даних.

Виклад основного матеріалу. Управління активами в інвестиційній діяльності передбачає прийняття рішень відносно цінних паперів, з яких формується інвестиційний портфель, та включає такі складники [1]:

- вибір інвестиційної політики, тобто формулювання основної мети, визначення пріоритетів;

- відбір інвестиційно привабливих цінних паперів, що забезпечують необхідний рівень дохідності, якому передує аналіз фондового ринку;

- обгрунтування адекватного співвідношення видів і типів цінних паперів для досягнення намічених цілей, тобто власне формування інвестиційного портфеля;

- моніторинг інвестиційного портфеля в міру зміни його параметрів для перегляду складу портфеля з метою підвищення його ефективності.

Вибір інвестиційної політики полягає в оцінюванні потенційних видів активів для визначення, яка частина активів буде ризикованою, а яка - безпечною з урахуванням як дохідності, так і ризикованості. Це дає змогу під час управління активами будувати та реалізовувати збалансовану інвестиційну політику.

Аналіз цінних паперів, що обертаються на фондовому ринку, здійснюється на предмет визначення передбачуваної дохідності і рівня ризику для різних видів активів [2].

Сутність портфельного інвестування полягає у розподілі наявних інвестиційних ресурсів між різними видами активів залежно від цілей, які постають під час формування конкретного портфеля [5].

Слід зауважити, що ефективність формування інвестиційного портфеля пов'язана 3 використанням сучасної портфельної теорії. Портфельна теорія - це побудований на методах математичної статистики механізм оптимального формування інвестиційного портфеля за бажаним критерієм співвідношення рівня його дохідності та ризику. В основу цього механізму покладено концепцію «ефективного портфеля», формування якого спрямоване на забезпечення максимальної його дохідності за певного рівня ризику або мінімального рівня ризику за певної доходності. Іншими словами, за будь-якої комбінації заданих цільових параметрів формування портфеля інвестор повинен намагатися забезпечити найбільш ефективне поєднання по ньому дохідності і ризику [6].

Вихідне положення портфельної теорії полягає у тому, що значення дохідності окремого цінного паперу $\epsilon$ випадковими величинами, розподіленими за нормальним законом. Для визначення розподілу ймовірностей випадкового значення дохідності необхідно знати, якими будуть фактичні значення iï по періодах та яка ймовірність кожної величини. При цьому інвестора цікавить дохідність інвестицій протягом інвестиційного періоду, тобто майбутні значення дохідності, які на дату інвестування ще невідомі. Тому інвестор повинен оперувати майбутнім розподілом випадкової величини дохідності. Існують два підходи до побудови розподілу ймовірностей: суб'єктивний і об'єктивний, або історичний [8].

Під час використання суб'єктивного підходу інвестор передусім повинен визначити можливі сценарії розвитку економічної ситуації протягом інвестиційного періоду, оцінити ймовірність кожного результату та дохідність цінного паперу, що очікується при цьому. Суб'єктивний підхід має важливу перевагу, оскільки дає змогу оцінювати відразу майбутні значення дохідності. Але він не знаходить широкого застосування, оскільки практично дуже важко виконати оцінку ймовірностей економічних сценаріїв та дохідність, що очікується при цьому [3].

Напрактицічастішезастосовується об' єктивний підхід, який базується на припущенні, що розподіл імовірностей майбутніх значень дохідності практично співпадає з розподілом імовірностей історичних величин (тобто тих, що вже мали місце). Звідси, для отримання уявлення про розподіл величин дохідностей у майбутньому достатньо побудувати розподіл цих величин за певний період у минулому. На відміну від суб' єктивного методу, який припускає різні ймовірності значень дохідності, за об'єктивного методу кожне значення має однакову ймовірність, що дорівнює зворотній величині кількості спостережень [7].

Фактична дохідність портфеля цінних паперів визначається відношенням різниці між вартістю цінних паперів на дату розрахунку дохідності та на дату їх придбання до вартості цінних паперів на дату придбання [4].

Наприклад, порівнюються два альтернативних портфеля А і Б, вартість придбання яких дорівнює 600 тис грн. На певну дату вартість портфелів А і Б дорівнювала 640 тис грн і 695 тис грн відповідно. Звідси, фактична дохідність портфеля $\mathrm{A}-0,067$, або 6,67\%, а портфеля Б - 0,1583, або $15,83 \%$.

Очікувана дохідність портфеля визначається як середньозважена величина очікуваних значень дохідності пакетів цінних паперів, що становлять портфель.

Варто пам'ятати, що головною особливістю функціонування фондового ринку $є$ те, що всі його учасники діють в умовах неповної визначеності. Відповідно, результат практично будь-яких операцій купівлі-продажу цінних паперів не може бути точно передбаченим, оскільки всі або майже всі угоди наражаються на певний ризик. Ризик портфеля зумовлюється не лише індивідуальним ризиком кожного окремого пакету цінних паперів, а й тим, що існує ризик впливу зміни дохідності одного пакета на зміну дохідності інших пакетів, які є складниками інвестиційного портфеля.

Для того щоб визначити ризик портфеля цінних паперів, у першу чергу необхідно розрахувати ступінь взаємозв' язку та спрямованості змін 
дохідностей двох активів. Наприклад, якщо ціна одного цінного паперу підвищується, то зростає курс й іншого цінного паперу, і навпаки, рухи цін різноспрямовані або $є$ повністю незалежними один від іншого. Для визначення зв'язку між цінними паперами застосовують такі показники математичної статистики, як коваріація і коефіцієнт кореляції.

Коваріація і коефіцієнт кореляції є показниками взаємозалежності двох випадкових величин. Позитивна коваріація означає, що в русі дохідності двох пакетів цінних паперів простежується тенденція змінюватися в одних і тих самих напрямах: якщо дохідність одного пакета збільшується (зменшується), то і дохідність другого пакета також збільшиться (зменшиться). Якщо ж простежується зворотна тенденція, тобто збільшення (зменшення) дохідності одного пакета, то йому відповідає зниження (збільшення) дохідності другого пакета. У такому разі вважається, що між дохідностями цих двох пакетів існує негативна коваріація.

Нагадаємо 3 теорії математичної статистики, що показник коваріації призначений для виміру ступеня спільної змінюваності двох пакетів цінних паперів.

Однак використання показника коваріації $є$ не завжди зручним, тому що він має розмірність квадрату дохідності та не обмежується за величиною. Для коректного співставлення більше підходить використання відносного показника - коефіцієнта кореляції. Кореляція характеризує систематичний та зумовлений зв'язок між двома рядами даних. На фондовому ринку прийнято розглядати кореляцію різних пакетів акцій, або пакетів акцій i індексів. Коефіцієнт кореляції дохідності по двох фінансових інструментах інвестування може змінюватися від -1 (що означає повну негативну кореляцію між інструментами) до +1 (що означає повну позитивну кореляцію між ними). За нульового значення коефіцієнта кореляція між показниками дохідності відсутня.

Орієнтація на результати розрахунку коефіцієнтів кореляції сприяє проведенню обгрунтованої диверсифікації портфеля цінних паперів. Для максимально можливого зниження ризику за збереження потрібного рівня дохідності слід вибирати такі активи, дохідність яких матиме найменш можливу кореляцію.
Тож під час формування портфеля інвестору слід керуватися дохідністю, що очікується, і стандартним відхиленням. При цьому визначальну роль відіграє інтуїція: очікувана дохідність розглядається як міра потенційної винагороди, пов'язаної 3 конкретним портфелем, а стандартне відхилення - як міра ризику, пов'язана $з$ даним портфелем. Такий підхід базується на припущенні, що інвестор за всіма іншими рівними умовами віддає перевагу високій дохідності, якщо будуть задані два портфеля 3 однаковими стандартними відхиленнями. Якщо ж перед інвестором буде вибір між портфелями 3 однаковими рівнями очікуваної дохідності, то перевага віддається портфелю 3 мінімальним ризиком, тобто отриманню більшого доходу за мінімуму можливого відхилення.

Висновки. Отже, термін «портфельні інвестиції» може використовуватися в різних значеннях: як системний - для створення конкретного портфеля інвестицій (на відміну від індивідуального) або як просто спрямований на отримання прибутку без утручання в роботу цінного паперу. У міжнародних відносинах цей термін часто вживають у другому значенні.

Основною формою залучення іноземних портфельних інвесторів є продаж державного боргу. Виручені кошти підуть як на покриття дефіциту держбюджету, так і на погашення вже взятих кредитів. Як наслідок, іноземні портфельні інвестиції практично не перетворюються на реальні інвестиції, а отже, не мають серйозного впливу на економічний динамізм.

Для підвищення ефективності портфельних інвестицій необхідно змінити структуру залучених коштів шляхом збільшення частки інструментів власного капіталу та розподілу корпоративних боргових інструментів. Однак це стане можливим лише завдяки розвитку вітчизняного ринку цінних паперів та підвищенню довіри іноземних інвесторів до українських емітентів.

Таким чином, сукупність різноманітних цінних паперів, що належать інвестору, утворює портфель цінних паперів, формування якого має на меті забезпечити оптимальне поєднання вигідності (дохідності), надійності і ліквідності цих активів. А постійний моніторинг та оцінювання ризику інвестиційного портфеля за викладеними вище підходами сприятиме підвищенню дохідності інвестицій і подальшому розвитку фондового ринку.

Список використаних джерел:

1. Пересада А.А. Управління інвестиційним процесом : монографія. Київ : Лібра, 2017. 472 с.

2. Шевчук В.Я., Рогожин П.С. Основи інвестиційної діяльності : монографія. Київ : Генеза, 2017. 384 с.

3. Майорова Т.В. Інвестиційна діяльність : навчальний посібник ; 4-е вид., перероб. і доп. Київ : ЦУЛ, 2016. $376 \mathrm{c}$.

4. EBA report on big data and advanced analytics. 2020. URL: https://www.eba.europa.eu/ (дата звернення: 15.12.2021).

5. Каліна I.І. Трансформаційні тенденції розвитку інтеграції цифрових технологій. Наукові праці ДВНЗ «Донеиький національний технічний університет». Серія: економічна. 2019. Вип. 1. С. 124-131.

6. Дзюба П.В. Концептуальна структура теорії портфеля як парадигмальна основа сучасної теорії міжнародного портфельного інвестування. Науковий вісник Ужгородського наиіонального університету. Серія «Міжнародні економічні відносини та світове господарство». 2017. Вип. 15(1). С. 100-106. 
7. Задоя А.О. Портфельні інвестиції в Україну: шанси чи загрози? Академічний огляд. 2019. № 2(51). С. 81-90.

8. Третякова О.В., Харабара В.М., Грешко Р.І. Фондовий ринок України: особливості функціонування в сучасних умовах. Економіка та держава. 2020. № 5. С. 103-107.

\section{References:}

1. Peresada A.A. (2017) Upravlinnia investytsiinym protsesom [Investment process management]. Monograph, 472 p. (in Ukrainian)

2. Shevchuk V.Ya. (2017) Osnovy investytsiinoi diialnosti [Fundamentals of investment activity]. Monograph, 384 p. (in Ukrainian)

3. Mayorova T.V. (2016) Investytsiina diialnist [Investment activity], textbook manual, 4th ed., revised. and add, 376 p. (in Ukrainian)

4. EBA report on big data and advanced analytics (2020). URL: https://www.eba.europa.eu (European Union).

5. Kalina I.I. (2019) Transformacijni tendenciyi rozvytku integraciyi cyfrovyx texnologij [Transformational trends in the integration of digital technologies]. Scientific works of Donetsk National Technical University. Series: economic. Pokrovsk. Issue 1, pp.124-131. (in Ukrainian)

6. Dziuba P.V. (2017) Konceptualna struktura teoriyi portfelya yak paradygmalna osnova suchasnoyi teoriyi mizhnarodnogo portfelnogo investuvannya [Conceptual structure of portfolio theory as a paradigmatic basis of modern theory of international portfolio investment]. Scientific Bulletin of Uzhhorod National University. Series: International Economic Relations and the World Economy, no. 15 (1), pp. 100-106. (in Ukrainian)

7. Zadoya A.O. (2019) Portfelni investyciyi v Ukrayinu: shansy chy zagrozy? [Portfolio investment in Ukraine: chances or threats]. Academic review, no. 2 (51), pp. 81-90. (in Ukrainian)

8. Tretyakov O.V., Kharabara V.M., Greshko R.I. (2020) Fondovyj rynok Ukrayiny: osoblyvosti funkcionuvannya v suchasnyx umovax [The stock market of Ukraine: features of functioning in modern conditions]. Economy and State, no. 5, pp.103-107. 